\title{
THE HELMONTIAN GEORGE THOMSON \\ AND WILLIAM HARVEY: \\ THE REVIVAL AND APPLICATION OF \\ SPLENECTOMY TO PHYSIOLOGICAL RESEARCH
}

by

CHARLES WEBSTER

DURING THE last decade of Harvey's life, the medical theories of Joannes Baptista van Helmont came into prominence, following the posthumous edition of his collected works, Ortus medicinae (1648), edited by his son, Franciscus Mercurius van Helmont. This enigmatic and challenging collection of tracts revitalized opposition to Galenic medicine, reinforcing the influence of Harvey's work in physiology and anatomy. Both authors provided a wealth of new ideas which were assimilated in various ways in the new physiologies which developed after the discovery of circulation. Helmontian physicians were quick to accept circulation and Harvey's disciples explained physiological processes in terms of the new chemical theories. It was perhaps only the sharp vocational divisions of the period which prevented the explicit and peaceful amalgamation of the biological theories of van Helmont and Harvey.

Helmont's works were published too late to elicit much direct response from Harvey. His immediate reaction may have been to dismiss the Ortus medicinae in derisive terms along with the other 'Neoteriques', if John Aubrey's famous report is correct. $^{1}$ On the other hand, Walter Pagel has argued persuasively that there are strong underlying affinities of outlook between the two innovators, both in general monistic biological philosophy and in adherence to the ontological theory of disease. ${ }^{2}$ These similarities are most obvious from comments on general medical questions in Harvey's last work, De generatione (1651). There is also evidence that he became familiar with specific Helmontian cures, indicating a receptivity to empirical medicine quite consistent with his approach to other scientific issues.

Although Harvey's last work was published in 1651, it is clear from his correspondence that he retained an active and critical interest in new developments in physiology until the time of his death in 1657. An interesting and hitherto overlooked encounter during these years was with the young Helmontian physician George Thomson. Even at this time Thomson had an aversion to the London medical monopoly exercised by the College of Physicians, combined with a growing enthusiasm for van Helmont. After the Restoration he was to gain notoriety by his attempts to

\footnotetext{
1 John Aubrey, Brief Lives, ed. A. Clark, 2 vols., Oxford, 1898; vol. 1, pp. 300, 302.

- W. Pagel, William Harvey's Biological Ideas, Basle and New York, 1967; 'Harvey and Glisson on irritability with a note on van Helmont', Bull. Hist .Med., 1967, 41, 497-514.'Pagel and M. Winder, 'Harvey and the "Modern" concept of disease', Bull. Hist. Med., 1968, 42, 496-509.
} 


\section{The Helmontian George Thomson and William Harvey}

organize the Helmontians into a rival College of Chemical Physicians. ${ }^{3}$ This involved him in a vigorous and prolonged exchange of pamphlets with the defenders of the established order. In spite of rather unedifying contributions to the ephemeral polemical literature, his writings indicate a greater ability than most of his colleagues, who were empirics of doubtful reputation. Along with his friend George Starkey, he was an articulate exponent of Helmont's ideas. However until recently they have aroused very little comment from historians. ${ }^{4}$ This paper will draw attention to Thomson's claim to have pioneered the splenectomy experiment. This is of interest both for the association with Harvey which it occasioned and the repercussions which led to the widespread application of the technique in physiological enquiry.

\section{THOMSON'S CAREER AND MEDICAL OUTLOOK}

There is very limited information relating to Thomson's career, most of the evidence coming from his own writings in which he was obliged to provide evidence about his academic record, medical qualifications and political outlook in order to disarm critics who linked him with the illiterate empirics. ${ }^{5} \mathrm{He}$ was born in 1619 and probably educated in Kent, his family being sufficiently prosperous to prepare him for the standard academic medical education. With this in mind he lodged in London, seeking advice from medical men before commencing his university studies. However the civil war and death of his father interrupted these plans. Awaiting the resumption of normal conditions he travelled to France, returning to Weymouth in 1644, intending to take up residence in Oxford. Instead he joined the Royalist army and participated in the Cornish victories before being taken prisoner at Newbury in October $1644 .^{\circ}$ His medical studies were now recommenced in the rather unconventional surroundings of the Fleet prison. Upon release these studies were completed and he applied to the College of Physicians for a licence to practice medicine in London. He was duly brought before the censors "who appreciating my abilities to practise, told me that they would confer upon me a testimony thereof, if I paid such a sum of money demanded by them for my license'. ${ }^{7}$ This was the root of his growing antagonism to the College. Regarding this claim as excessive he decided to enter the medical profession by the commonly adopted alternative avenue, the Leyden M.D. First he obtained an M.A. from Edinburgh University, enabling him to register at Leyden in June 1648. His thesis was submitted one month later. ${ }^{8}$ Upon return to England,

8 P. M. Rattansi, 'The Helmontian-Galenist controversy in Restoration England', Ambix, 1964, 12, 1-23; Sir Henry Thomas, 'The Society of Chymical Physitians' in E. A. Underwood ed., Science, Medicine and History, 2 vols., Oxford, 1953; vol. 2, pp. 56-71.

'For an excellent study of Starkey, see R. S. Wilkinson, 'George Starkey, physician and alchemist', Ambix, 1963, 11, 121-52.

- See Henry Stubbe, Campanella Revived, or an Enquiry into the History of the Royal Society, London, 1670, Sig. A3r and p. 21. Stubbe accused the Royal Society of fostering the Society of Chemical Physicians. 'I hoped the Physicians would consult their common interest in opposition to the Thomsons and Odowds'. Joseph Glanvill agreed with this sentiment, in $A$ Short Reply to H. S., London, 1670, pp. 11-12.

- Thomson, A letter sent to Stubbe, 1672, p. 4. (All references to Thomson's writings will be given as short titles. For full details, see the Appendix.) S. R. Gardiner, History of the Great Civil War, 1893 ed.1, vol. 2, pp. 7-19.

7 A letter sent to Stubbe, p. 4. The manuscript Annals of the College of Physicians substantiate Thomson's account. He was examined by the censors in December and January 1647/8.

${ }^{8}$ Catalogue of the Edinburgh Graduates, Edinburgh, 1857, p. 65, 19 June 1647. R. W. Innes-Smith, English Speaking Students of Medicine at the University of Leyden, Edinburgh, 1932, p. 232. 


\section{Charles Webster}

rather than submit to the College of Physicians, he settled outside London to practise at Romford in Essex. He was rapidly converted to Helmontian medicine which he asserted saved him from the 'learned ignorance' of scholastic medicine. This involved some sacrifice, since the reformed method was less lucrative, while he 'moiled, toil'd and drudged like a Collier for the acquisition of salutiferous Remedies'. ${ }^{2}$ In about 1656 he performed the splenectomy experiment. This brought some celebrity and closer contact with London medicine. Hence he soon moved to London, where he practised as an unlicensed physician until his death in March $1677 . .^{10}$

His position was secure until the Restoration, when the College of Physicians attempted to enforce its medical monopoly. This was resisted by the Helmontian physicians, who organized their rival College of Chemical Physicians during the 1665 plague when the responsibilities and reputation of the Helmontians were at their zenith. ${ }^{11}$ Thomson emerged as one of the most effective and active Helmontian pamphleteers. His literary activity continued unabated until his death. A list of his publications is given as an appendix to the present article.

Thomson's enthusiasm for van Helmont was expressed with religious fervour. The new system was 'ordained in these last times by especial providence of God, for the comfort and relief of distressed Man'.12 The first priorities in the new medicine were pathology and the search for chemically prepared specific remedies. Accordingly Thomson was not convinced that current preoccupation with anatomy was of immediate benefit to medicine. He pointed out that the discoveries of Harvey and Aselli had not brought improvements in medicine, asserting that the lodging place of diseases would not be discovered with the surgeon's knife. ${ }^{13}$ Indeed he hoped that chemistry would undermine surgical techniques such as phlebotomy in medicine. Emphasis should accordingly be given to 'Pyrotechnical Anatomy'. ${ }^{14}$ However anatomy was not entirely to be disregarded. It was a necessary factor in the physician's training. Indeed he regretted that the College of Chemical Physicians had admitted 'mock Chymists, no whit exercised in Anatomy and Botanicks' ${ }^{15}$ As an empirical study, anatomy was spared the scorn reserved for logic, grammar, and other parts of the liberal arts education. Thomson's greater sympathies were with the methodology of Bacon and the virtuosi of the Royal Society, aiming 'at a competent knowledge of applying and appropriating Medicines ... as to Real, Useful, Beneficial worth in his employments'.16

\section{THOMSON'S SPLENECTOMY AND HIS MEETING WITH HARVEY}

Thomson accepted Harveian circulation and applied it to his Helmontian explanations of disease. The splenectomy experiment brought him into direct contact with Harvey.

- Thomson, Misochymias, 1671, pp. 10-11.

${ }^{10}$ Thomson lived at Duke's Place, Aldgate; until after 1671. In 1674 he was living at Soper Lane, Cheapside. For his death, see the Harvard University Library Broadsheet, 'An Elegy upon the Death of the Much Lamented, Able and Learned Physician Doctor Thomson. Who Dyed March the 11 th 1677.'

11 See note 3.

12 Thomson, Galeno-pale, 1665, p. 4.

18 Ibid., p. 25.

14 Ibid., pp. 2, 28.

15 Ibid., p. 104

10 Thomson, Misochymias, pp. 9, 45. 


\section{The Helmontian George Thomson and William Harvey}

The first reference to splenectomy was made incidentally in 1665 , when it was used as evidence for the limited value of anatomy in medicine. ${ }^{17}$ More serious use of the experiment was made when replying to critics who attempted to rank him with the illiterate empirics O'Dowd and Trigg. Thomson vindicated himself by drawing attention to his academic record and pioneer role in splenectomy, an operation which he claimed had gained popularity due to his endeavours. The impact of this experiment had been immediate, involving Thomson in debates with physicians and surgeons in London. It also attracted the attention of Harvey, Boyle and the celebrated amateur physician Henry Pierrepoint, Marquis of Dorchester. However, as seen from the full description of this enterprise given below, Thomson was aggrieved that the established physicians had plagiarized his discovery.

Now, because you'18 and your Co-partners glory in the knowledge of Anatomy, I would that
Ingenious men take notice that I have Reason to speak something for my self, being as well
versed therein as most of you; yea, I have performed one of the most remarkable operations in
Europe, i.e. Splenectomy, the compleat Experiment of cutting the Spleen out of a Dog, whose
life afterward was prolonged to about two years; then loosing it by accident. Having accomplished
this Anatomical Manufacture, I addressed myself to Doctor Harvey, who was exceedingly
affected with the novelty of the Experiment; I also communicated the manner of the Dissection
and Accidents coming upon it to a noted vapouring Anatomist among you, ${ }^{10}$ who at first admiring
and commending the fact, putting me to the trouble to bring the Dog up to London, ploughed in
interim with my Heifer, congregating some of the Chirurgions (who, as I was told, would have
laid an hundred pounds it could not be done) and working according to my directions, made an
execution of the Spleen; so that before I returned to London (about a Moneth after the Relation)
a Dog called Asplenos was running up and down his house. The Marquess of Dorchester who
sent me to meet him in Greys-Inn-Garden, that he might confer with me about the matter, and
testifie that I was the first who made this Experimental Dissection to a purpose. To confirm
it more, Squire Boyl offered to give (as Doctor Currer told me
was forthwith taken pounds for the Dog; but
that he might enjoy the use of my Asplenical Dog, and the two Cholic stones (which Doctor
Harvey beheld with admiration, urging me to repose them in his new built Fabrick, that he
might expose them to publick view in the Anatomical Theatre: which I granted, on condition
he would do me right; but his design was quickly laid aside and quashed, after he had consulted
with his Colleagues, lest I should get too much Credit and Practice by this Agyrtising mode.22

Although Thomson gave no date for his experiment, the meeting with Harvey must have taken place after February 1654, when the Harveian Museum was opened and before June 1657 when Harvey died. This dating is substantiated by further evidence discussed below.

The failure of physicians to recognize his priority caused increasing irritation. In 1675 Thomson promised: 'I shall further vindicate (as the first) the Credit and Propriety of Splenectomia, i.e. the cutting of the Spleen out of a Dog (the Animal surviving the Operation two years and a Quarter) Usurped by Dr. C. S. [Charles

17 Thomson, Galeno-pale, p. 26.

18 Henry Stubbe.

19 Probably Harvey's disciple, and prominent Fellow of the College of Physicians Dr. Charles Scarburgh, later knighted. His anatomical lectures at the Surgeons' Hall, assisted by Christopher Wren, were a considerable success. Like Thomson and Harvey he was a Royalist. For evidence on this identification, see below. For Scarburgh, see Dictionary of National Biography; W. Munk, Roll of the Royal College of Physicians, 3 vols., London 1878, vol. 1, pp. 252-55.

${ }_{20}$ William Currer, a Leyden M.D. who was a friend of Boyle and Ashmole. For Boyle's references to splenectomy see below. Currer became a member of the College of Chemical Physicians.

${ }^{21}$ Christopher Terne who obtained a Leyden M.D. in 1647. He became a Fellow of the College of Physicians in 1655. Like Scarburgh he lectured to the surgeons. W. Munk, Roll of the Royal College of Physicians, vol. 1, p. 272.

2s Misochymias, pp. 59-60. 


\section{Charles Webster}

Scarburgh] appropriated by the Virtuosi, now set down in the list of their Transactions'. ${ }^{23}$

Undoubtedly he had noticed that Thomas Sprat had begun his list of original contributions of the Royal Society to medicine and anatomy with the "cutting out the Spleen of a Dog'. ${ }^{24}$ This prompted him to write a fuller account of splenectomy, but this was left unpublished at his death. However it was edited by his disciple Richard Hope and published along with two other tracts, a necroscopy on a plague victim in 1665 , and an account of the treatment of Ann Taylor of Romford, Essex, who voided three stones under the influence of Thomson's chemical remedies. ${ }^{25}$ These stones, obtained in 1655, were probably those shown to Harvey.

Thomson's De Splenectomia Historia ${ }^{26}$ followed the main lines of the earlier account, amplifying some details, but omitting mention of Harvey. The author was primarily concerned to give full details of his experiment and repeat the accusations of plagiarism. The date of the experiment was given as 1657 during his medical practice at Romford. If this is recorded correctly, Thomson's meeting with Harvey must have been one of the latter's final scientific encounters. The critical importance of this date will be discussed below when discussing the merits of Thomson's priority claim.

The splenectomy was performed by making a lateral incision just beneath the ribs on the left side of the abdomen of a medium-sized dog. The spleen was clearly exposed along with part of the stomach and intestines. The spleen was then carefully excised and the viscera replaced. The wound was then bound and treated with a chemical balsam. The gradual restoration of the dog to health was described at length. By the third day the appetite was restored. After a temporary setback due to abdominal abscesses, its normal behaviour was resumed. The rest of the particulars were very like his earlier narrative. He described how his experiment caused local and then more general interest and debate, leading to a visit to London, where his secret was revealed and the asplenic dog shown to the influential anatomist whom we can identify as Charles Scarburgh. The latter's ingratitude was violently denounced, earning such epithets as Suffeti Hectorisus, famigeratus Anatomicus, and praesatus Galenicus. During Thomson's absence in the country the anatomist called some surgeons together and performed the operation according to the new method, claiming priority for himself (bene meritum sibi arroget; or, ejus inventorem \& principium actorem in publico indigne asserebat). The virtuosi 'galeni fautores' then repeated this plagiarism.

The dog itself lived for a further two years and three months, being normal in its behaviour-'Robustam, Agilem, famelicosum, ac maxime pugnacem, sine liene vixisse'. Its death was the result of an attack by a large dog. The post-mortem showed that its internal organs were in good condition, the position of the spleen being shown by a small residue of parenchymatous tissue.

Thomson's three posthumous Latin tracts are an ample vindication of his superiority over most of his Helmontian associates. By emphasizing splenectomy he illustrated his ability to take part in the debate familiar to the leading medical controversialists.

23 Thomson, The Direct Method of Curing Chymically, 1675, p. 200.

"Sprat, History of the Royal Society, London, 1667, p. 223.

${ }^{25}$ Thomson, Experimenta admiranda, ed. Richard Hope, London 1680.

26 Ibid., pp. 115-57. 


\section{The Helmontian George Thomson and William Harvey}

However, this was not a random anatomical enterprise, but was turned to the purpose of discrediting Galenic physiology. Hence he may have been aware of earlier splenectomies, but he claimed to have been 'the first who made this Experimental Dissection to a purpose'. He asserted that his experiment had crucial significance and would render vacuous current disputes on the function of the spleen, when it became recognized that it was possible for animals to live normally without this organ. 'Hoc Experimento Splenectomico a me primo expresse confecto, e vestigio abortae sunt lites inter Ingenia solertiora, unde comparatum est Animal perfectum sine liene vivere posse'. 27

In the tradition of Harvey's vivisection experiments which had undermined the Galenic theories of the cardiovascular system, Thomson regarded his own experiment as a crucial evidence against other aspects of Galenic physiology and humoral pathology. It will be seen from the following discussion that medical men were quick to exploit this experiment, with full recognition of its physiological implications.

\section{THE REVIVAL OF SPLENECTOMY}

Most seventeenth-century discussions of the spleen gave passing recognition to ancient ideas on splenectomy. It is possible that the experiment was performed in various cultures in the Eastern mediterranean in the pre-Christian era. Certainly the idea of performing the operation on men and animals was then current. Pliny speculated that a swollen spleen (a likely condition in mediterranean countries where malaria was prevalent) caused an impediment in running; hence athletes had an operation to remove this organ. He also reported that splenectomy could be performed in animals without deleterious effects. ${ }^{28}$ On the other hand Caelius Aurelianus doubted whether the operation could be performed safely on man. ${ }^{29}$

In later centuries interest in this operation was preserved particularly by the Turks. During the sixteenth century various medical visitors to Turkey claimed that the operation was performed there. The first may have been Benedetto Ramberti in 1539, who reported that splenectomy was performed on mail carriers to facilitate their running. ${ }^{30}$ This was noticed widely in medical literature for the next century. This may have encouraged western surgeons to perform the operation. The first well-substantiated attempt was by the celebrated Italian surgeon, Leonardo Fioravanti, with the assistance of Andriano Zaccarello at Palermo in 1549. They removed a scirrhous spleen weighing thirty-two ounces from a young woman. This caused astonishment in the vicinity. ${ }^{31}$ Since Fioravanti's works had a considerable vogue,

27 Ibid., p. 124.

${ }^{28}$ Pliny Historiae naturalis Lib. XI cap. 80, 'Peculiare cursus inpedimentum aliquando in eo quamobrem minuitur (inuritur) cursorum laborantibus. et per vulnus etiam exempto vivere animalia tradunt.'

"0 Caelius Aurelianus, V libros morborum chronicorum, ed. J. C. Amman, Amsterdam, 1709, p. 453.

20 Ramberti, Delle Cose de Turchi. Libri Tre, Venice, 1539, p. 19. Among the later writers to mention the Turkish splenectomies: Jean Riolan fils, derived his information from François Rousset the French surgeon, while Harvey quoted Giovanni Tommaso Minadoi, who took part in Harvey's degree ceremony at Padua. Minadoi had practised medicine in Turkey.

${ }^{\prime 1}$ Fioravanti, Tesoro della vita humana . . . Diviso in libri Quattro, Venice, 1570, Lib. II, cap. 8; pp. 25-7. Harvey's teacher Hieronymus Fabricius, attacked Paduan attempts to restore this operation. Opera Chirurgica, Frankfurt, 1620, p. 208. 


\section{Charles Webster}

this case history was frequently cited, the possibility of splenectomy being discussed briefly in many surgical works. Indeed the operation was probably performed occasionally in cases where the spleen was damaged. For instance Harvey recorded in his Praelectiones anatomicae that Minadoi reported the operation from Turkey and that Mr. Gillous (? Gillow's) spleen had been safely removed. ${ }^{32}$

Experimental splenectomies on animals were also attempted occasionally in the century before Thomson's enterprise. Vesalius advocated vivisection techniques for the study of visceral physiology, indicating briefly that he had excised the spleen from a dog. Although Harvey made no reference to this experiment, it was performed by his colleague Robert Fludd. ${ }^{33}$

Throughout this period splenectomies had been sporadic, with little reference to sustained physiological investigation. Quite suddenly splenectomies became more popular, the significance of the experiment being recognized by medical men throughout Europe. During 1656 and 1657 the experiment emerged in both correspondence and publications. Thomson's role in this movement must remain a matter of conjecture. If his experiment was performed in 1655 or early the next year other evidence substantiates his account of the spread of the experiment to London scientific circles. However, if it was performed in 1657 , as the Latin account suggests, he was merely reflecting the current fashion. In view of his strenuous and repeated priority claims, and accusations against Scarburgh, who became widely credited with the experiment, it is quite possible that Thomson was its originator, lapse of memory twenty years later causing an error of one year in the Latin account. In this case his meeting with Harvey would have been in 1656, a more likely date in view of Harvey's death in the following year.

The European popularity of this experiment was largely due to another Helmontian physician, Johannes Christianus Agricola, a friend and pupil of Thomas Bartholin, who visited London during the Protectorate. Here he became associated with the circle of Hartlib and his physician son-in-law, Frederick Clodius, who was his host (hospes meus \& insignis Chymicus). ${ }^{34}$ Agricola's letters exhibit a strong interest in anatomy and chemical theories of disease. The first reference to the splenectomy experiment found by the present author is in a letter from Martin Bogdan to his teacher Bartholin, dated Paris, 17 July 1656. Bogdan repeats information from an earlier Agricola letter, describing briefly the method of excising the spleen, the treatment of the wound with balsamo sulfuris Rulandi and observations on the lymphatic system by the anatomist Scarburgh (Scarbourtus ibidem Anatomicus). ${ }^{35}$ Soon afterwards, Bartholin's correspondents throughout Europe were familiar with 'de modo exscindendi Lienen Anglicano'.36

The first published reference to these experiments was probably Thomas Wharton's

32 Harvey, Anatomical Lectures, ed. Gweneth Whitteridge, Edinburgh and London, 1964, p. 134.

33 Fludd, Anatomia Amphitheatrum effigie triplici, Frankfurt, 1623, p. 101. 'Ego vero lienem canis a perito chirurgo exemptum esse cognovi incisione, vivente adhuc cane.'

s4 Letter of Agricola to Bartholin, 19/29 February, 1656, in T. Bartholin, Epistolarum medicinalium, Centuria IV, Copenhagen 1663-7; Cent. II, pp. 631-4. Epist. 71.

${ }^{25}$ Ibid., Cent. II, Epist. 77, p. 648.

36 Ibid., Cent. II, Epist. 79, p. 651, George Seger to Bartholin, 3 December 1656. 


\section{The Helmontian George Thomson and William Harvey}

Adenographia (London, 1656). Here he recognized that the excision of the spleen undertaken in dogs, cats and in principle probably possible in other animals also, necessitated reconsideration of its physiological role. ${ }^{37}$ Shortly afterwards, Thomas Bartholin devoted a chapter of his Historia anatomicarum rariorum to splenectomy. ${ }^{38}$ He gave a complete translation of Fioravanti's operation and an account of the recent English experiments on dogs, cats and pigs, based on the letters of Agricola. Scarburgh, Thomson's bête noire, was singled out for particular praise, 'Scarborough Anatomico Londinensi and dignissimo magni Harvei successore'. Scarburgh's method was generalized for various mammals. It was similar to Thomson's directions, but with direct reference to ligaturing prior to excision. A further account was given of George Joyliffe's method, which involved bandaging the wounds, but no use of balsam. ${ }^{39}$ It will be remembered that Joyliffe attained celebrity as a medical student, for his role as a pioneer investigator of the lymphatic system. After qualifying at Oxford he settled in London, dying prematurely in 1658. His experiment was singled out for mention by Boyle, who made no reference to Thomson, in spite of the latter's assertion that the chemist had wished to purchase his asplenic dog.

And because I have not yet met with any author, that professes not to relate this experiment ... upon the credit of others, but as an eye-witness; I am content to assure you that that dextrous dissector, Jolive . . . did last year, at my request, take out the spleen of a young setting-dog I brought him: and that it might not be pretended, the experiment was unfaithfully or favourably made, I did part of it myself, and held the spleen ... in my hand, whilst he cut asunder the vessels reaching to it, that I might be sure that there was not the least part of the spleen left unextirpated. ${ }^{\infty}$

One final noteworthy figure at this pioneer stage was Christopher Wren, the prodigy of the Oxford circle. Among his juvenalia is a description of the splenectomy, an experiment which may have been called to his attention by Scarburgh, whose anatomical lectures to the surgeons were assisted by Wren. ${ }^{41}$

Splenectomy maintained its popularity, being performed at public and private meetings of physicians in various parts of Europe. In 1662 Jacob Holstius reported to Bartholin that his friends had showed him an asplenic dog at Leyden. Bartholin himself described the grand scene when the Royal surgeon performed splenectomies at Copenhagen in the presence of the King. ${ }^{42}$ During a visit to Paris in about 1665 , the promising young physician Renier de Graaf performed the experiment while investigating the functions of the spleen. ${ }^{43}$ In the record of his visit to England in 1663, Olaus Borrich was informed about splenectomy by various members of the

\footnotetext{
27 Wharton, Adenographia op. cit., 1659 Amsterdam ed., p. 13. 'Probabile quoque est, lienem vase excretorio destitui, vel ex eo quod pars haec ad vitam admodum necessaria ist, ut patet, quia canes \& feles (forteque nonnulla alia animalia, si experimentum ad ea quoque extenderetur) execto liene non admodum infeliciter vivunt.'

${ }^{88}$ Bartholin, Historia anatomicarum rariorum centuria IV, Copenhagen, 1657; Cent. IV, cap. 5, pp. 216-21.

io Ibid., pp. 217-18. For Joyliffe, see Munk, Roll of the Royal College of Physicians, op. cit., vol. 1, pp. 280-81.

io Boyle, The Usefulnesse of Experimental Natural Philosophy, Oxford, 1663; quoted from Boyle's Works, ed. T. Birch, London, 1772, vol. 2, p. 68.

11 Christopher Wren (ed.), Parentalia, London, 1750, pp. 237-38.

12 Bartholin, letter to J. Langelot, 1662, in Epistolarum op. cit., Cent. III, Epist. 64, p. 258. Letter of Holstius to Bartholin, Cent. III, Epist. 72, p. 300.

is De Graaf, Tractatus Anatomico-medicus de succi pancreatici (1668), quoted from Opera ommia, Leyden, 1677, pp. 524-25.
} 


\section{Charles Webster}

Royal Society, including Walter Charleton who claimed to have performed the experiment at Bath some years before. ${ }^{44}$ As mentioned above, Sprat's History of the Royal Society (1667) gave the experiment as one of the Society's contributions to medicine. Reports of the experiment by Timothy Clarke and Edmund King were entered into the Journal of the Society in 1667, but they induced no productive physiological debate. ${ }^{45}$ Finally, the predominantly medical Academia Naturae Curiosorum in Germany included a summary of the recent medical and experimental splenectomies in the first volume of their published transactions, Miscellanea curiosa medico-physica 1670 (pp. 82-3).

These references indicate the rapidity with which splenectomy and related anatomical techniques became adopted by physiologists. Whatever Thomson's role in this movement, his aims were accomplished. Very quickly a vigorous debate on the physiology of the spleen was provoked which brought the Galenic theory under critical scrutiny.

\section{SPLENECTOMY AND THE FUNCTIONS OF THE SPLEEN}

Thomson's assertion that his contemporaries believed the spleen to be the seat of the black bile, or melancholy humour was engendered by his anti-Galenic sentiments. Nevertheless, it was not entirely misleading. The Galenic theory, albeit in a modified form, dominated the textbooks and was accepted by many of the leading physicians of Harvey's generation. However the historian should not overlook that on this issue as on most others there was a diversity of opinion mirroring the physiological debates of antiquity..$^{46}$

Galen's theories about the spleen were always associated with an undercurrent of antagonistic views, the most extreme emanating from Erasistratus, who regarded the spleen as a useless organ. It would be interesting to know whether this point of view had been induced by the experience of successful splenectomies. Most ancient authorities were in agreement in regarding the spleen and liver as closely associated in their functions. Galen's emphasis was on the spleen's attraction of black bile from the liver, where it had been concocted. This melancholy humour was then voided into the stomach. Either directly or indirectly the spleen was also relevant to sanguinification, the followers of Alexander of Aphrodisias emphasizing the role of its blood-forming activity. In the seventeenth century this point of view had such influential exponents as Sennert, Hoffmann, Spigelius and Bartholin. ${ }^{47}$

There also appeared theories which had no clear roots in antiquity. The pioneer monograph De liene (1578) by Franciscus Ulmius proposed that the arterial blood

4 Bartholin, Epistolarum op. cit., Cent. IV, Epist. 92, pp. 516-40; 518, 521, 537.

${ }^{4} \mathrm{~T}$ T. Birch, History of the Royal Society, 4 vols., London 1756-60, vol. 2, pp. 173-8, 2-30 May 1667.

16 There are no adequate discussions of early ideas on the physiology of the spleen, but see, $\mathrm{S}$. V. Steinheim, Doctrina veterum de liene, Hamburg, 1833; R. Lerner, Anatomie und Physiologie der Milz bei M. Malpighi, Dissertation, Wurzburg, 1957, pp. 48-55. Julius Preuss, Biblisch-talmudisch Medicin, ed. Berlin, 1923, p. 249. For ancient splenectomy, E. Gurlt, Geschichte der Chirurgerie und ihrer Ausibung, Berlin, 1898, I, 35, 396, 497, 568; II, 330; III, 722-23.

"Daniel Sennert, Institutionum medicinae, Wittenberg, 1611, quoted from Opera omnia, 3 vols., Lyons, 1654-6; vol. I, pp. 328-29. C. Hoffmann, De usu lienis, Leipzig, 1615. A. Spigelius, De humani corporis fabrica, Venice 1627; Lib. VIII, cap. 14. T. Bartholin, Anatomia Reformata, ed. Hague, 1666, pp. 98-109. These authors differed greatly in their anatomical and physiological interpretations of the spleen and its vascular system. This subject is currently being studied in detail by Mr. Andrew Wear of Imperial College, London; his comments on the subject have been greatly appreciated by the author. 


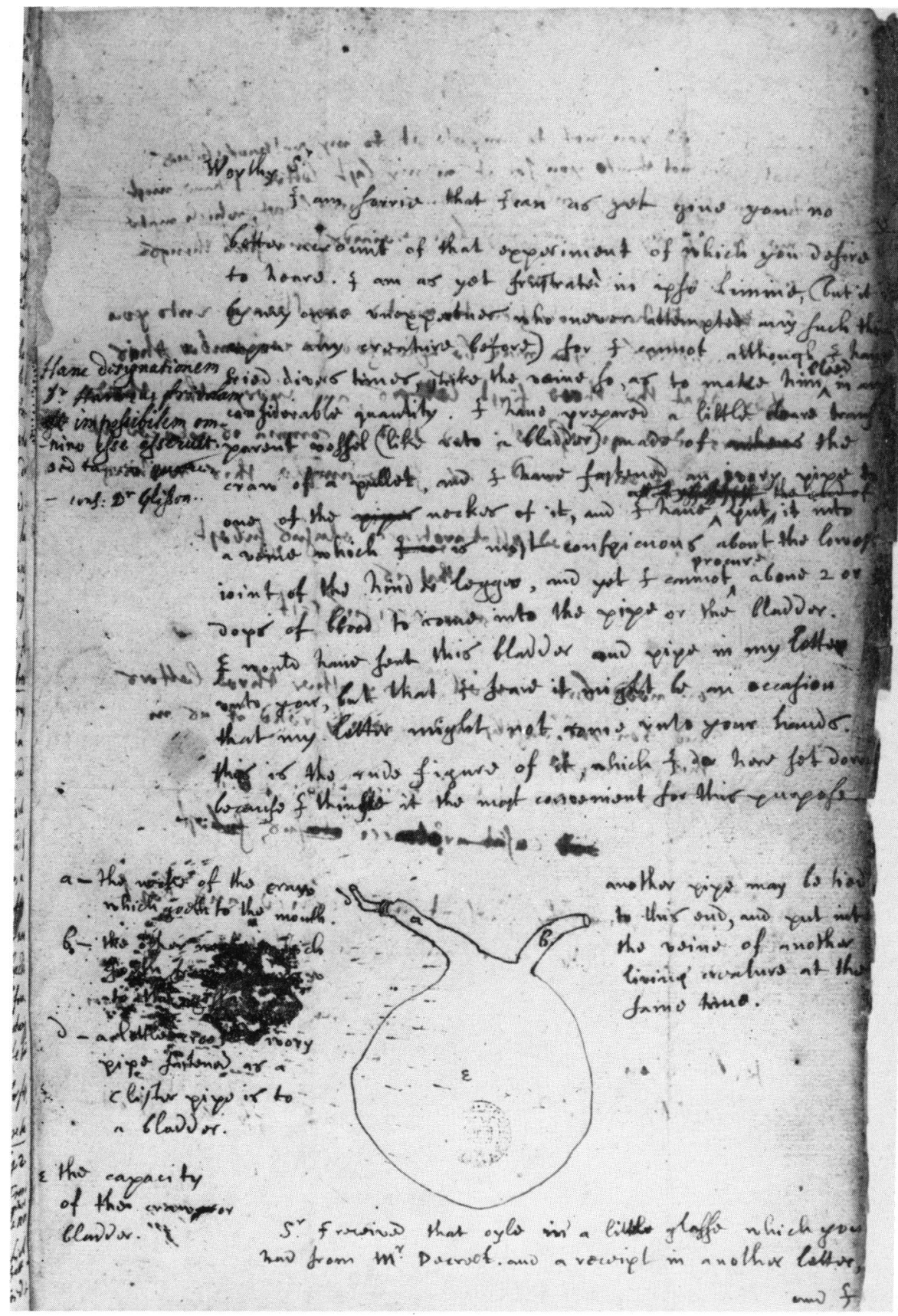

Letter from Francis Potter to John Aubrey, 5 December 1652. Bodleian Library, Oxford, Aubrey MS. 6, f.61r. 


\section{The Helmontian George Thomson and William Harvey}

was inaugurated in the spleen rather than the left ventricle of the heart. Francis Glisson, emphasizing the associated nervous and arterial innervation of the spleen suggested that a succus nutritius derived from the nerves was added to the blood of the spleen..$^{48}$ Glisson's idea had a short but influential life, finding echoes in Sylvius and Mayow. The former believed that animal spirits and the latter that nitroaerial particles were introduced into the blood from the nerves of the spleen. ${ }^{49}$

As would be expected, van Helmont adopted a strongly individualistic attitude to the spleen, emphasizing the anatomical and physiological association with the stomach. The spleen lay against the stomach as if nourishing it with a network of arteries. $^{50}$ In physiological action the two organs were associated together as if in a conspiracy or Duumvirate (Id circo amborum viscerum conspirationem decrevi vocare Duumviratum). ${ }^{51}$ The spleen was the seat of the archeus which watched over the functions of the stomach, like the sun over the planets. In particular the spleen controlled the ferment reponsible for digestion. The Galenic humours were regarded as a fiction, the excrementary black bile being replaced by the physiologically active ferment.

Harvey's position was not clearly defined, but drew together undogmatically points from various anatomical and physiological findings. He recognized that the spleen was widely developed among higher animals, being a valuable ancillary to the liver and stomach, without being essential to their functioning. It was not a vital organ like the heart or liver since it was not a source of vital heat. Harvey drew an analogy between the spleen and a wash-house. It was developed as a subsidiary organ contingently necessary for the functioning of the vital organs. 'Contra splen per accidens necesse ob defendum iecoris et ventriculi ut washows to the kitchin'.52 Following Harveian circulation, the clarification of the anatomy of the viscera and its blood vessels by such authors as Highmore, Glisson and Malpighi, and the splenectomy experiment, it was clear that traditional views on the spleen required radical modification.

The detailed study of the vascular system which came in the wake of Harvey's discovery rendered the traditional pathways relating to the spleen untenable. Galenists had believed in a flow of humours in the veins from the liver to the spleen and thence to the stomach, pancreas or small intestine. Employing ligature experiments, Highmore and Glisson showed that valves and the natural flow of blood precluded blood or injected liquids flowing from the liver to the spleen, or from the spleen to the stomach and intestines. ${ }^{53}$ These observations undermined not only Galen's views on the passage of melancholy humour to the stomach, but were also unsympathetic to van Helmont. Both relied on a connexion between the spleen and stomach through the vas breve.

18 Glisson, Anatomia hepatis, London, 1654; quoted from Amsterdam ed. 1659, pp. 523-24.

49 Franciscus Sylvius, Disputationes medicae, Amsterdam 1663; Disputatio 5, p. 12. John Mayow Tractatus Quinque, Oxford, 1674; Treatise IV, cap. 5.

so Ortus medicinae, Amsterdam, 1648, p. 292. "Vicinus ergo Splen stomacho foris incumbit, quasi eundem foveret vitali arteriarum contextu.'

51 Ibid., p. 292.

s2 Harvey, Anatomical Lectures, op. cit., pp. 132-4.

63 These techniques were developed in Highmore's Corporis humani disquisitio anatomica, Hague, 1651, and Glisson's Anatomia hepatis, London, 1654. 


\section{Charles Webster}

As an alternative it was proposed that the humour drained from the spleen through the pancreatic duct to the duodenum. De Graaf disproved this by showing that extirpation of the spleen did not hinder the flow of pancreatic juice in a dog. ${ }^{54}$ For Wharton the splenectomy experiment and characteristic anatomical structure of the spleen suggested that this organ was not fulfilling the normal secretory or excretory functions. Such organs could not be removed without severe effects on life and reproductive capacity. ${ }^{55}$

As Thomson suggested, the above observations instantly rendered vacuous much of the contemporary debate on the spleen. Although providing little positive guidance, they undermined many of the premises of earlier debates. Nathaniel Highmore's reaction was typical. In 1651 he had adopted the Galenic position and criticized the classical alternatives in detail but in $\mathbf{1 6 6 0}$ he abandoned belief in the separation of melancholy humour by the spleen with its subsequent passage to the stomach. He expressed no regrets, since experimental evidence necessitated that he should recant his errors. ${ }^{56}$ It was still possible to maintain the humoral view of the spleen, but only in such an attentuated form that its identity was lost. It became more attractive to elaborate new theories based on contemporary chemical and physical theories. An obvious consequence of splenectomy was the revival of Erasistratus' theory that the spleen was functionless. While this idea was widely canvassed, it was not accepted. Bartholin's correspondent, Jacob Holstius gave a characteristic reply to this suggestion-it was unacceptable because it contradicted the prevalent teleogical view of nature. 'Contra Naturae hoc providentiam est, quae nec necessariis deficit, neque otiosis abundat.' ${ }^{57}$

Thomson responded to current anatomical knowledge by subtly changing the ground of the Helmontian theory, until it accorded with the consequences of circulation and splenectomy. It was no longer possible to maintain van Helmont's direct anatomical association of the Duumvirate. Indeed, Thomson fostered all errors on this subject on to the Galenists. The new anatomy undermined the four humours, while indicating the prophetic nature of van Helmont's theories. The Duumvirate were now seen to have the joint function of concocting the blood, the first stage occurring in the stomach to produce the chyle. This was then passed into the arterial bloodstream, where its second concoction occurred. The spleen and arteries restored the Archaeus to its vital condition, again able to fulfil its role in the first concoction of the stomach. Thus by emphasizing the physiological role of the circulating blood Thomson was able to maintain a modified Duumvirate theory, in which the spleen had a significant physiological function, but was not entirely indispensable. ${ }^{68}$

\footnotetext{
s4 De Graaf, De succo pancreatici, op. cit.; Opera omnia, pp. 524-25.

ss Wharton, Adenographia, op. cit., p. 13.

so Highmore, Exercitationes duae, quarum prior De passione hysterica: Altera De Affectione Hypochondriaca, Oxford, 1660. 'licet in Disq. Anatomica sententiam hanc studiose defendere conati sumus; dummodo nullum aliud excogitare potuimus officium. Sed cum difficultabitus urgeri plurimuis observavimus; neque munus illiud apte lieni convenire posse invenimus, non pigebit ab erroribus recedere \& mutare sententiam.' p. 115.

${ }^{57}$ Jacob Holstius to Bartholin, 1662; in Epistolarum, op. cit., Cent. III, Epist. 72, p. 300.

s8 Thomson, Experimenta admiranda, 1680, pp. 145-53. There was between the stomach, arteries and spleen, 'necessitudo stricta: ut alter alterius continuo proscat opem, utriusque Bene vel Male esse mutuo concatenato', p. 153.
} 


\section{The Helmontian George Thomson and William Harvey}

Richard Lower made a similar attempt to adapt his ideas on the functions of the spleen to the theory of circulation. He accepted the Helmontian ferment in the stomach, but denied its transit from the spleen to the stomach. A more likely place of origin was the arterial blood, since asplenic dogs displayed an unabating hunger. ${ }^{59}$

The most celebrated anatomical study of the spleen during this period was by Malpighi. ${ }^{60}$ However his views on the physiology of this organ were relatively unsuccessful, finding few adherents, although he had one notable exponent in Johann Bohn. ${ }^{61}$ Bohn noted the recent technical innovations of splenectomy and ligaturing the splenic vein, the latter being attributed to Malpighi. These authors returned to Galen's view of the interdependence of the spleen and liver but with a clear understanding of the direction of blood movement. It was suggested that the spleen was a blood reservoir or gland in which bile was chemically synthesized. The excision of the spleen resulted in a more rapid blood flow to the liver, its dilation and a coarser constitution of the secreted bile. Thus there was a return to the glandular view of the spleen which had been criticized by Wharton a decade earlier. Whatever the merits of these splenectomies, ground work was effectively laid during this period for the anatomical and physiological investigation of the spleen, the participants exhibiting a high degree of accurate anatomical observation and perceptive experiments, including the splenectomy. One immediate extension of this technique was to the pancreas. The applicability of organ excision or manipulation to the study of the pancreas was quickly realized. De Graaf used splenectomy to prove the independence of the pancreas as mentioned above. Shortly afterwards Johann Conrad Brunner impressed by the success of splenectomy in dogs, was induced to investigate the effects of extirpating the pancreas, leading to the first experimental induction of diabetes. ${ }^{62}$

\section{CONCLUSIONS}

Looking back from the seventeenth century it was recognized that the spleen had since antiquity been subjected to diverse and conflicting interpretations. While it had been possible to achieve a general consensus on the functions of the major organs, less confidence was felt in interpretations of the spleen. Even Galen's interpretation, closely integrated with his influential humoral physiology, was frequently criticized. The spleen was recognized as a great mystery. Bohn's comment on traditional attempts to define a distinctive role for the spleen represents a widely held opinion. 'Lien corporis oeconomiae praestet, ubique tenbrae, ubique silentum.' ${ }^{63}$

The spleen and its associated black bile hence provided a weak link in the Galenic system, to be exploited by the opponents of humoral physiology. The most dramatic and effective critic of this system in the mid-seventeenth century was van Helmont. He asserted that his recognition that there was no black bile in nature enabled him to abandon the whole humoral system and Galen's views on the function of the organs. ${ }^{\text {64 }}$ Although with a weaker anatomical basis, Helmontian medicine coincided in many

so Lower, Tractatus de corde, London, 1669, p. 198.

-o Malpighi, 'De Liene' in De viscerum structura exercitationes anatomicae, Amsterdam, 1669. For a good discussion of Malpighi, see Lerner, cited above, note 46.

1 Bohn, Circulus anatomico-physiologicus, Leipzig, 1686. Cap. 18. 'De lienis usu'.

-2 Brunner, Experimenta nova circa Pancreas, Amsterdam, 1683, pp. 5-6.

os Bohn, op. cit., pp. 285-6.

ot Helmont, Ortus medicinae, op. cit., p. 307. 


\section{Charles Webster}

of its goals with the tradition emerging from Harvey's work. In particular they were united in emphasizing the primacy and unifying function of blood.

In view of the foundations laid by Harvey and van Helmont, it is not surprising that their first generation of disciples made rapid strides in evolving new systems of physiology, undermining many aspects of the humoral system. Investigations of the spleen between 1650 and 1666 could be paralleled by other case histories. Techniques of investigation which had been known since Vesalius, were given a new impetus and direction by Harvey's discovery and van Helmont's iatrochemical theories. Considerable advances were made in the understanding of the anatomy and functioning of parts. Splenectomy, which had been known since antiquity, was now meaningfully applied.

From the evidence cited above, it is quite possible that the revival of this experiment was undertaken by George Thomson in 1655 or 1656. As a supporter of both Harvey and van Helmont it would have been appropriate for him to concentrate attention on the spleen. Significantly Harvey ignored vocational disputes, adopting an inquisitive attitude to Thomson's experiment. Unfortunately his old age prevented his exploiting this discovery. However his colleagues not only exploited splenectomy, but also adopted a proprietary attitude, which may have suppressed evidence about Thomson's role in the revival of the experiment. In 1665 when his rivals had not publicized their plagiarism, Thomson was content to make passing reference to splenectomy, but after Sprat's History claimed the experiment for the Royal Society, he felt obliged to assert his own priority. Priority debates in medicine were very common at this time, often involving international rivalry, a characteristic example being the debate over the original blood transfusion. In Thomson's case, vocational issues were involved. During the puritan revolution the medical monopoly of the College of Physicians was undermined, the Helmontian physicians emerging as an articulate and effective opposition party. While it was possible for the aged Harvey to stand aside from this debate, it was not appropriate for his younger colleagues to collaborate amicably with unlicensed physicians who were undermining the practices and reputation of the College. It was even more outrageous for the Helmontian to be given publicity in the new Harveian Museum.

For the history of medicine the priority issue is less important than the scientific consequences. In the climate of this period, ideally suited to experimental science and the development of formal and informal societies to foster this study, splenectomy quickly became one of the characteristic components of the experimenter's repertoire. Besides disconnected performances there were serious attempts to assess the physiological implications of the experiment. This was accompanied by more sophisticated vivisection techniques and detailed anatomical study, rendered easier by improved optical devices. Hence this period produced a burst of new thinking on the spleen, sections on this organ being included in various anatomical monogaphs, including Wharton on glands (Adenographia, 1656); Glisson on the liver (Anatomia hepatis, 1654); Lower on the heart (De corde, 1669); Malpighi on the viscera (De viscerum structura, 1669); as well as the medical and physiological writings of Thomson, Mayow, Bohn, Sylvius and Highmore. These works moved away from humoral physiology and radically revised ideas on the anatomical structure of the spleen and 


\section{The Helmontian George Thomson and William Harvey}

its relations with other organs. It proved easier to undermine traditional theories than construct enduring new ones in terms of the chemical theories of Helmont and Sylvius. It was intelligently recognized that splenectomy did not necessitate a return to Erasistrastus's view of the uselessness of this organ. On the other hand, the evidence implied that the spleen was involved in a subtle and subsidiary function, substantiating the outlook expressed in Harvey's lecture notes. While the conditions were established for more convincing interpretation of the spleen, the problem was still beyond the grasp of the seventeenth-century physiologists. The dark and silent mystery which Bohn described was to remain for physiologists in many subsequent generations.

\section{APPENDIX}

\section{A LIST OF GEORGE THOMSON'S WRITINGS}

1. Disputatio medica inaurguraris [sic], de apoplexia quam divino aspirante numine, Leyden, 1648.

2. Loimologia. A consolatory advice, and some brief observations concerning the present pest, London, 1665.

3. Galeno-pale: or, a chymical trial of the Galenists, that their dross in physic may be discovered, London, 1665.

4. $\pi \lambda a v o-\pi v i \gamma \mu o s:$ or a gag for Johnson that published animadversions upon Galeno-pale, London, 1665.

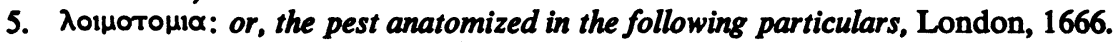

6. anjartiaois or, the true way of preserving Bloud in its integrity, and rectifying it, if at any time polluted and degenerate, London, 1670.

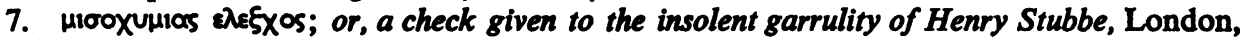
1671.

8. A Letter sent to Mr. Henry Stubbe, wherein the Galenical method \& medicaments, as likewise bloud-letting in particular, are offered to be proved ineffectual, or destructive to mankinde, London, 1672.

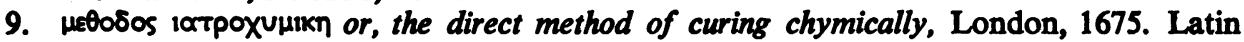
trans. ed. G. Hennick, Frankfurt-a.M, 1686.

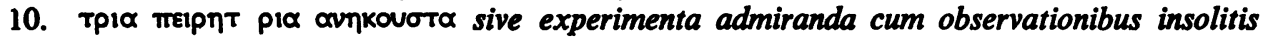
medicochymicis . . . in loimotomiae synopsi in gratiam alienigenarum, lythocolo, splenotomia, Ed. Richard Hope, London, 1680. 